\title{
Chapter 8: Religion and Integration in a Multifaith Society
}

\author{
James Jupp
}

\begin{abstract}
Australia has been defined in many different ways over the past two centuries. From 1788 to the separation of Queensland in 1859 it developed as a series of British colonies, each one answerable to London rather than to anywhere else. Being British was its defining ethnic feature and anyone who was not British, and preferably of Anglo-Celtic origin, was not always welcome, though not excluded. Preference was given to the Protestant Germans and Scandinavians, but Catholic Italians and Croatians were less welcome and there was considerable criticism of the Irish despite them being British subjects. Within a generation Australia was further refined as a 'white' British society with many local common links additional to those with the United Kingdom. This was consolidated by Federation in 1901 and continued to be essentially maintained until the Second World War. Non-Europeans were rigidly excluded, while white British immigrants were generously subsidised to settle ${ }^{1}$.
\end{abstract}

The Aboriginal population declined rapidly and was expected to die out. The great majority of Australians subscribed to one or other religious denomination imported from the British Isles, of which the largest at Federation were Anglicans, Catholics, Methodists, Presbyterians and Baptists. Australia was a very homogeneous society in terms of origins, languages and religions and certainly much more so than the two major immigrant societies of the time in the United States and Canada ${ }^{2}$.

\section{Social cohesion}

Only one 'cultural' factor threatened the social cohesion of this British outpost - hostility between Protestants and Catholics ${ }^{3}$. Underlying this was hostility between British and Irish and the conflicting interests of labour and capital. But ethnic and religious conflict was muted by the exclusion of all elements believed to threaten peace and harmony, namely non-Europeans and, de facto, non-Christians. This did not mean that Australia was a deeply religious society. On the contrary, secularism was strongly entrenched in the political élite and

Jupp, J (1998). Immigration, Oxford University Press, Sydney.

2 Jupp, J (ed) (2009a). The Encyclopedia of Religion in Australia, Cambridge University Press, Melbourne.

3 Hogan, M (1987). The Sectarian Strand, Penguin, Ringwood, Victoria. 
led to the withdrawal of public funding from religious schools throughout the second half of the nineteenth century. This particularly alienated the already distinctive Catholic quarter of the population, whose politics were thereafter determined by what they regarded as an injustice ${ }^{4}$. This resentment lasted into the 1960s, making religion a simmering political issue but one which was largely submerged by the tensions between labour and capital.

One intellectual consequence of this history is that academic historians have dealt with religious issues to only a limited extent, while other social scientists have concentrated on secular, and especially economic, questions or attempts to define Australia in uniform terms which ignored the religious divide. One major exception to this blinkered view was the historian Manning Clark, but he was more concerned with spiritual and moral dimensions than with denominational struggles. Despite a growing group of religious historians, other historians tended to marginalise religious issues, with few exceptions like Douglas Pike's history of the South Australian 'paradise of dissent's. With the growth of the political science profession in the 1960s, attention was largely focused on the political role of Catholics, especially in Victoria ${ }^{6}$. Opinion polling, which had once shown Catholics to be predominantly Labor voters, increasingly excluded a religious question. The sociology of religion was also neglected ${ }^{7}$.

\section{Managing diversity}

Despite the apparent uniformity of Australia into the 1950s, there was always a concern with external threats and with internal stability and cohesion ${ }^{8}$. Since 1901 immigration has been 'micromanaged' in the sense that there has never been an 'open door' for everyone who has wished to settle, despite the recognition that Australia had a very small population relative to its size and proximity to heavily populated Asian societies. This has meant that at every stage some types of people are welcome while others are not or are excluded altogether. The criteria have always been the utility of immigrants for Australia. This was generously defined for the British at least until the 1970s. Their utility was that they came from the founding stock and required no special services. They spoke English (unlike many Irish, Highland Scots and Welsh in the nineteenth century), were nominally Christian and could, therefore, be absorbed into existing institutions, jobs and neighbourhoods with little expense

\footnotetext{
O'Farrell, P (1992). The Catholic Church and the Community, University of New South Wales Press, Sydney. Pike, D (1957). Paradise of Dissent, Melbourne University Press, Melbourne.

Truman, T (1959). Catholic Action and Politics, Georgian House, Melbourne.

Mol, H (1985). The Faith of Australians, George Allen and Unwin, Sydney.

Jupp, J, Nieuwenhuysen, J and Dawson, E (eds) (2007). Social Cohesion in Australia, Cambridge University Press, Melbourne.
} 
or trouble. The extent to which others met these criteria was usually important for being selected or rejected. Everyone arriving lawfully since 1901 has had to be inspected at the entry point, except for a handful of seamen jumping ship - which was illegal under British maritime law. Others, arriving 'unlawfully' (without a visa) have recently been subjected to increasingly draconian controls beyond the normal procedures of deportation.

Religion was not one of the measures used to determine the status of immigrants. Religious discrimination by the Commonwealth was unconstitutional under the 1901 constitution s.116, but this was of only marginal importance, especially as Irish migration had dropped off in the 1890s never to recover. A minor exception to 'whiteness' was made for Lebanese Christians (Maronite and Melkite Catholics) who formed a small but distinct community in Sydney from the 1890s'. Some Muslims were accepted as 'white', including several Albanian families in the 1920s and others from the Balkans. A small number of Muslims, who had established residence before 1901, were allowed (like resident Chinese) to enter and leave under a permit system ${ }^{10}$. Sikhs who had served in the British Indian army were given some concessions in the 1920s for their service to the empire. But the entire non-Christian population did not exceed one per cent until the admission of Turks (who were defined as 'white') in the late 1960s. Of the non-Christians at least half were Jewish ${ }^{11}$.

Religious variety only became significant with the ending of the White Australia policy between 1966 and 1972. Physical appearance and descent had been central, but many Asians of 'mixed race' and Christian religion were admitted in the 1960s. These, like the British migrants they resembled in most respects except birthplace, did not need 'managing' nor were they seen as presenting a problem. Many became active in the already established Christian churches. Chinese and other Asian students were required to return home once their studies were completed. Australian Jewish Welfare was active in bringing in refugees from Nazism in 1938 and Holocaust survivors after $1945^{12}$. The Jewish community was expected to service the welfare needs of their own people and there was marked opposition to their arrival from conservative politicians and media. The Australian Council of Churches also sponsored Orthodox Russian Christians from China after the Communist victory of 1949, continuing a long tradition of Protestant support for the Orthodox.

Essentially the management of diversity did not become an issue until the 1950s (except in Aboriginal affairs). Religious organisations took an important role in welcoming immigrants and assisted in the creation of churches and congregations,

9 Batrouney, A and Batrouney, T (1985). The Lebanese in Australia, AE Press, Melbourne.

10 Raikovski, P (1987). In the Tracks of the Camel Men, Angus and Robertson, Sydney.

11 Tavan, G (2005). The Long, Slow Death of White Australia, Scribe, Melbourne.

12 Benjamin, R (1998). 'A Serious Influx of Jews', Allen and Unwin, Sydney. 
including those of different denominations, as with the Anglican support for some of the smaller Orthodox groups from Eastern Europe. In that sense, the first wave of post-war entrants integrated through already existing networks. A substantial majority of the refugee Displaced Persons were Catholics ${ }^{13}$. The existing churches also took a role in the Good Neighbour Councils set up with Commonwealth funding from 1950. These embraced existing religious and charitable institutions, strongly favoured assimilation and declined to accept affiliation from ethnic organisations. Their major beneficiaries were British, Dutch and German immigrants and Displaced Persons, who were favoured in public opinion but started to decline in numbers by the 1970s. This exercise in integration depended on bringing individuals into already established religious networks with strong charitable traditions.

The central problems perceived by governments in those early days were communication and acceptance. Communication was tackled by the Adult Migrant English Programme, which became the largest item in the budget of the Immigration Department. This taught 'survival English' and still does, although it now offers a wider range of courses. Acceptance was tackled via a propaganda campaign showing that all new migrants loved Australia and were 'just like us' (including 'spot the Aussie' picture displays at Good Neighbour meetings). As many of the anti-Communist refugees were blonde and blue-eyed this was not too difficult. There was some hostility, especially to the use of other languages in public. Religion was not an issue, as all were presumed to be Christians and most were Catholics. However, behind the assimilationist façade, there was the steady creation of ethnic and religious organisations and networks, most of which still exist. There was, then, integration but not full assimilation.

This system of encouraged assimilation steadily eroded as immigration shifted towards southern Europe and the arrival of hundreds of thousands of Italians, Greeks, Maltese and Yugoslavs. All were deemed to be 'white', even the Turks who were assisted in substantial numbers from 1968. Turks were the first (and only) Muslim group to be assisted with publicly funded fares. But there was very little opposition. They were supported by the Returned Services League (for their bravery at Gallipoli) and by the motor industry (for their role in German car factories) and have remained a rather unproblematic community in concentrated working class districts of Melbourne and Sydney. What their 'values' are is scarcely understood and they are essentially a classic industrial proletariat with limited English. The Greeks and Italians and large contingents of Lebanese and Vietnamese refugees, admitted under relaxed conditions in the mid-1970s, were important in dismantling the Good Neighbour assimilationist movement. They were the backbone of the multicultural movement which had

13 Kunz, E F (1988). Displaced Persons: Calwell's New Australians, Australian National University Press, Sydney. 
been launched in Melbourne in the early 1970s and was enthusiastically encouraged by Malcolm Fraser later in the decade ${ }^{14}$. The major policy document of this period was the Galbally report of 1978, which has shaped policy ever since ${ }^{15}$.

Here again, religion was not emphasised. Solutions were secular, including welfare, the creation of local migrant service points, the subsidy of Ethnic Communities Councils and their national body, extended translation and interpreting services, the multilingual Special Broadcasting Service, funding assistance to ethnic welfare bodies on the same basis as others and, eventually, funding of religious schools (Christian and otherwise) on an equal basis. This latter was in financial terms and its long-term implications much more important than many of the Galbally proposals, but it escaped critical comment and was not mentioned by Galbally. Most of the conservative opponents of multiculturalism were strong proponents of religious schools.

Many supporters of multiculturalism deplored public subsidies to religious institutions, although the main benefits came from tax concessions rather than direct grants. Distinct education, social and welfare provision grew rapidly, but multiculturalism was seen by most Australians as involving dances, festivals and food. The protection of s. 116 ensured that non-Christian schools were generously supported, which had not been the case in Britain or other European states. This did not arise in the United States where there was no public provision for religious institutions other than very generous tax breaks, some of which were comparable to those in Australia.

\section{The new global conflict}

The official definition of 'culture' as somehow excluding religion naturally influenced public policy towards 'ethnic groups'. These were defined in terms of national origins, language and citizenship, replacing the racial basis officially used for most of the century before the 1970s. Yet this definition was increasingly irrelevant to classifying many immigrants from outside Europe, who began to dominate the intake. The old argument as to whether Jews were a race, a religion or an ethnic group had been glossed over for many years and probably worried Jews more than anyone else. However, in 1996 Samuel Huntington launched a new approach to cultures which became increasingly important in Australia as in other immigrant receiving societies ${ }^{16}$. In his view the lines of future conflict would correspond to those between 'religious/cultural' traditions rather than nation states. Such states were often 'cleft' or 'torn' between alternative cultures,

14 Lopez, M (2000). The Origins of Multiculturalism in Australian Politics 1945-75, Melbourne University Press, Melbourne.

15 Galbally, F (chair) (1978). Migrant Services and Programs, AGPS, Canberra.

16 Huntington, S P (1996). The Clash of Civilizations and the Remaking of World Order, Simon and Schuster, New York. 
most relevantly in the case of Yugoslavia. In a rather fanciful passage he even extended this analysis to Australia, which was 'torn' between its European origins and its Asian location.

Huntington's approach was influential on policy makers in the United States and seemed increasingly relevant as Islamic militancy influenced the Islamic revival which had been spreading since the 1920s from the Middle East and South Asia and was now reaching developed Christian societies through globalised migration. Huntington's general propositions gained enormous influence through the destruction of the World Trade Centre in New York in 2001 and the resulting 'war on terrorism'. This 'war' had been going on for many years in the Middle East but had been largely ignored by the major powers, which were preoccupied with the Cold War between liberal democracy and communism. However it became threatening just as that 'war' came to an end and it rationalised a continuing militant stance by the United States in world affairs. The new 'war' began to impinge on domestic politics of Europe and North America, with terrorist acts in the US, Britain, Spain, the Netherlands, Germany, France and Russia. Religious hostilities were also central to the violent collapse of the state of Yugoslavia, which Huntington had correctly defined as a meeting place for the three 'cultures' of Catholicism, Orthodoxy and Islam.

The impact of all of this on public policy was detrimental to the development of multiculturalism, which had been proceeding slowly but surely in Europe, North America and Australasia. The first reaction was to define the crisis as requiring more vigorous immigration controls, as the $9 / 11$ bombers were Arabic immigrants to the USA. However, the European incidents shifted the emphasis to locally born Muslims, opening up the fear that there were large and growing elements who had not only not been assimilated or integrated but might be hostile to the dominant society and all its values. This view was strongly endorsed by John Howard for Australia, as it was by a range of Western politicians. Howard had been publicly hostile to multiculturalism ever since the Bicentennial debates of 1988 and now saw the political opportunity to reverse public policy without unduly alienating 'ethnic' voters.

At a political level, then, it does not need a very sharp analytical mind to understand why states like the Netherlands totally reversed their previous welcome to non-European immigrants and to religious diversity. When prominent individuals were being murdered in the streets or threatened with death for criticising Islam, such a dedicated plural democracy rapidly reassessed its previous tolerance. A major factor in shifting attitudes was the rapid increase in the votes of racist parties in states such as Austria, Switzerland and Denmark. However this did not apply to Britain, Canada or Australia. The rise and fall of One Nation in Australia was over before 9/1 $11^{17}$. 
No similar movement affected Canada. But what did affect all these liberal democracies, which had adopted multicultural approaches, was a shifting of the political debate in favour of the new concept of 'integration' and the centrality of 'values'. These developments gave an incentive to social scientists to take a new interest in religion, but few did so in Australia ${ }^{18}$. Politicians and public servants continued to generalise rather than to specifically attack Islam. Efforts were made to encourage and consult 'moderate' Muslims. Muslims were appointed to advisory positions, but none succeeded in entering the national parliament, until 2010.

\section{Integrating religion and the religious}

From 9/11 onwards, the management of diversity shifted ground in most democracies from concern with language and welfare services to anxiety about religion, values and loyalty. In the early suspicious days of non-British immigration there had been concern about Communist sympathies among Greeks and Italians, some of whom were excluded via security clearance. Many got in nevertheless, making the Greeks a bastion of the ALP Left in Victoria and South Australia. There was much less concern officially about fascist and Nazi sympathies, except in the Jewish community. Later concerns were expressed about possible war criminals coming in from Viet Nam, Lebanon and Yugoslavia. But all of these undemocratic entrants remained law abiding, confining their views within their own communities and in their own languages. Communism, fascism and nationalism are all secular creeds, held by minorities. However the Middle Eastern and Asian immigrants who became so prominent from the 1970s, were frequently defined by their religion rather than by their nationality or secular ideologies. The Lebanese had been disrupted by a series of civil wars based entirely on religious adherence, which they brought with them to Australia. Indians, Sri Lankans, Egyptians, Malaysians, Iranians, Ethiopians, Yugoslavs and Sudanese all came from societies in which self definition by religion was often more important than formal nationality. In many cases they also came from civil war situations in which human values had become seriously distorted.

Ethnic minority threats to Australian social stability and an ordered society were quite limited and found mainly among criminals in the drug trade. The gang wars, which killed thirty people in Melbourne within a few years, had a significant Lebanese and southern European element, although at least one criminal family was of Irish descent. The rather less vicious marijuana industry had a strong Calabrian influence, which extended to some city markets and rural areas. Vietnamese criminals were significant in some suburbs of Sydney and

18 Hassan, R (2008). Inside Muslim Minds, Melbourne University Press, Melbourne. 
Melbourne. Few were notably religious, although several had Catholic funerals. In the most violent confrontation between Anglo-Australians and Lebanese the Cronulla riot of 2005 - the aggressors were locally born Anglo-Australians. Compared with such problems in Europe or North America, Australia was quiet and cohesive. Religion had nothing much to do with any of these crises, although anti-Muslim slogans were used at Cronulla.

The 'war on terror' had to have a target, like all wars. Australian authorities (as elsewhere) were careful not to identify the 'enemy' in religious terms. The Tamil Tigers of Sri Lanka (who were not Muslims) were charged with supporting a terrorist organisation, albeit one which was not proscribed in Australia. But all organisations proscribed by Australia were Muslim, which was not the case for the much larger American list. No terrorist act was recorded on Australian soil. But the rapid expansion of anti-terrorist laws made advocacy and financial support for 'terrorist' organisations very serious and heavily punishable offences. It was under this legislation that a Muslim imam, Benbrika, and his disciples were prosecuted and sentenced to long prison terms in 2008.

Despite past suspicions about the Irish, the Italians, the Vietnamese and the Lebanese, no ethnic group had in the past been officially nominated a threat to Australian social cohesion, and certainly no religious group since at least the 1890s. Whatever unpublished instructions may have been sent to overseas posts, no public condemnation of entire ethnic or religious communities was made at the official level. However the long-term consequence of the 'war on terror'(as elsewhere), was to strengthen the requirements for entry and naturalisation, to institute a test of knowledge and values for intending citizens, and to seek 'moderate' Islamic leaders who might act as influences against the terrorist minority (whoever they might be ). Public formulation shifted from multiculturalism to integration, accomplishing in a short period what the Howard government's slow death approach had not yet achieved. Positively, academic centres of Islamic studies shot up everywhere and experts on terrorism appeared from nowhere. With some rare and unfortunate exceptions, the major Christian denominations remained aloof from attacks on the Muslim religion. The growing ecumenical movements began to expand outwards from their Christian bases ${ }^{19}$. But there was no agreed Islamic leadership and government attempts to create one were unproductive.

19 Cahill, D, Bouma, G, Dellal, H and Leahy, M (2004). Religion, Cultural Diversity and Safeguarding Australia, Australian Multicultural Foundation, Melbourne. 


\section{Religious integration}

Apart from the draconian new laws and a rapid expansion of security agencies, the main objective of government was to manage religious diversity by encouraging 'integration'. This magic word had been used officially in Australia in the interim between assimilation (to 1966) and multiculturalism (from 1973). It was never clearly defined, nor has it been yet, at least in Australia. However its popularity at the annual Metropolis conference in Bonn (Germany) in October 2008 suggests that it has secured considerable support. Metropolis is an agency of the Canadian government, where multiculturalism was invented in 1968. It brings together a wide range of academics and officials to debate ethnic affairs and immigration. It has, regrettably, had little support from Australia except when it met in Melbourne, but its deliberations are certainly reported to the Immigration Department.

Obviously integration is a more appropriate term than assimilation when dealing with religious communities. Jews have maintained their distinctive life in Australia for two centuries. Assimilation sounds the death knell to their religion in the opinion of most Jews. Muslims are not going to become Christians and neither are Hindus or Buddhists. Within Christianity there are more ecumenical relationships than ever before. But the Orthodox and Catholics have been negotiating reunion since the $15^{\text {th }}$ century and nothing much will happen in a hurry. Nor are the Sydney Anglicans likely to unite with the Catholics, despite agreement on several issues such as sexual morality and the ordination of women. So the old question 'assimilate to what?' will not produce an answer in religious affairs.

Integration holds out the prospect of close co-operation with agreement to differ, which is already advancing among the major denominations and distinct religions. This means, however, that there will still be substantial religious variety, with allegiances to various centres outside Australia and the use of languages other than English. It may also mean that some practices, inconsistent with liberal democracy and social equity, will go on being condoned by the more conservative clergy or their overseas superiors. One hope expressed by government is that native-born clergy will be trained in Australia, thus emulating the policy of the New South Wales Catholic Church nearly a century ago. As in the United States, churches which previously conducted their affairs in another language will move over to English to retain the support of the young. To some extent this has already happened. However some of the most dangerous militants have been locally born and perfectly fluent in English. The incorporation of non-Christian religious leaders into positions of authority, including as elected politicians, is a long way off. There is only one Muslim 
in the Commonwealth parliament and the first such member of the New South Wales upper house was only elected in 2009. This is a worse record than in Britain, Canada or New Zealand.

An ambiguity in the concept of integration is whether this refers primarily to individuals or to social groups. The assimilationist expectations of the 1950s were that within a few years 'New Australians' would be indistinguishable from their local fellows. This did not (and could not) happen for many of them. It is even less likely now that immigrants are drawn from a much wider range. Accepting the values of democracy in an affluent and secure society is more probable. This is problematic when Muslims see the Australian government, in alliance with others, bombing Muslim villages and occupying Muslim countries. Muslims can hardly fail to have noticed that most of the asylum seekers interned under the Howard government were Muslims, although the Immigration Department never publishes official figures based on religion. The unjustified treatment of Dr Haneef in 2007-2008 was also specifically directed against a Muslim ${ }^{20}$. The 'war against terrorism' recruits its own terrorists. Presumably one expectation of integration is that a sense of unity with co-religionists somewhere else should wither and die. This has not yet happened for Irish Catholics, Muslims, Jews, Armenians or most of the Orthodox Christians.

The tables following this chapter suggest that a high degree of collective integration is already taking place. But this is not the same as saying that individual members of religious communities will integrate at the same rate or with the same enthusiasm. The level of Australian citizenship is exceptionally high for some of the European religions (such as the Greek, Macedonian and Serbian Orthodox), which grew in size in Australia mainly in the 1960s (see Table 1). The level is lower for more recent arrivals such as Buddhists and Hindus, mainly from China, India, Malaysia and Fiji, but this is a consequence of recent arrival rather than reluctance to naturalise. Australian citizenship had become easy to achieve, at least until the waiting period was doubled by the Howard government. No matter how 'exotic' a religion may be by previous Australian standards, its adherents were anxious to become citizens, often seen as a measure of integration. The low levels of citizenship for Hindus reflect the recent arrival of Indians in general and of temporary students in particular. But Melkite Catholics (95.3 per cent), Ukrainian Orthodox (93.1 per cent). Druse (90.5 per cent) and Armenians (94.6 per cent) all have very high levels of citizenship, despite being unmistakably 'ethnic' churches. One important factor in the future, created by public policy, will be the very large numbers admitted under temporary visas who may not be eligible for citizenship.

20 Ewart, J (2009). Haneef: A Question of Character, Halstead Press, Canberra. 
The Tables in general show that 'traditional' religions from the British Isles still retain the overall loyalty of the majority of Australians. Non-Christian religions rose from 1.4 per cent of the total in 1901 to 5.6 per cent in 2006, more than one million and the highest level in Australian modern history. But this covers a wide variety of belief systems, often very decentralised. Christian denominations were more likely to feel pressure from the well-funded and efficient 'American' religions and especially Pentecostalism, than from Buddhism, Hinduism or Islam. Apart from acquiring citizenship, another measure of integration is educational and occupational success. By this standard, Jews (with 33 per cent graduates) and Hindus (41 per cent) are exceptionally well integrated, while Pentecostalists, Buddhists and Muslims are at the national level (Table 3). The Hindu figures represent the very large numbers of students now coming from India, many of whom will be eligible for permanent residence once they graduate, but who are less likely to have dependent children counted for their religion. Briefly, nonBritish and non-Christian religions seem well integrated into Australian society, while often retaining many quite distinctive traditions and cultures of their own. There is little reason to suppose that religious denominations as a whole may reject democratic values, but no guarantee that some individuals may not be attracted to violence and terror.

\section{Conclusions}

As public policy discourses move from 'multiculturalism' to 'integration', nationally and internationally, the religious factor in cultural diversity still remains at the margin of Australian public debate. Yet the very change in approved terminology would not have happened had it not been for the rise of Islamist militancy and the violent attacks on institutions and individuals in the past decade. The proverbial 'elephant in the room' grows larger by the hour. Its presence is the major factor in the tightening of citizenship requirements in previously liberal societies like Australia, Canada and the Netherlands. Australia has so far escaped the reactions of European societies like Switzerland, France and Denmark, which aim to erase visual evidence of the Muslim presence. But 'values' are tested as a requirement for final integration into majority society as a legal citizen. These values are all conceived of as secular, liberal and democratic and are reinforced by general knowledge requirements, which skirt around religion altogether by emphasising history, politics and even sport.

The basic dilemma is that all Western democracies conceive of themselves officially as secular, with a clearly defined division between 'church and state' ${ }^{21}$. This applies especially strongly to states such as the United States, the United

21 Fergusson, D (2004). Church, State and Civil Society, Cambridge University Press, Melbourne. 
Kingdom and its former colonies, Germany and the Scandinavian democracies. Yet many of these still retain established churches, while the United States is usually presented as the most deeply religious of all democratic societies, with the obligatory exhortation 'God Bless America' at all political gatherings. This contradictory tradition means, among other things, that religions are free of requirements to sustain equality between men and women or even to pay many taxes, while being eligible for a wide range of subsidies ${ }^{22}$. Religions are truly privileged and this is rarely challenged, except in the typically rigorous French Republic.

These contradictory approaches to one of the major cultural divisions in society - organised religion - makes the public discussion of issues surrounding social cohesion increasingly bizarre. The argument is really about whether Islam and Muslims can be 'integrated' into Christian and Enlightenment inheritances. Yet official multiculturalism in all its variants has skirted around the 'elephant', concentrating on languages, values, customs and 'culture' and social justice issues such as racism, refugees and equality of access to social and economic goods. The basic assumption of policy makers has been that religious issues should be left alone and 'mainstream' religious organisations should be privileged and secure from political interference while, at the same time, being allowed to exert legitimate pressures upon the political process ${ }^{23}$.

The social science disciplines have been just as cautious in approaching these dilemmas as politicians and public servants. In the Enlightenment tradition many academics in Western democracies are secular rationalists, with only the Catholic Church presenting a carefully crafted alternative set of views. Thus economists see integration as equal access to the labour market for the equally qualified, and immigration policy as contributing to improving the quality of the labour force and expanding demand and productivity. Demographers see immigration as essential to limit the effects of falling birth rates. Political scientists see religions as influences on public opinion - and hence on voting - or as elements in pluralist bargaining for measurable advantages. Sociologists and psychologists explain religious loyalties, without fully coming to grips with the question why such loyalties may persist over centuries when secular beliefs change quite rapidly. Many social scientists are uncomfortable with the concept of values, as well they might be.

Thus when governments develop 'evidence based' integration policies they normally do so in a rather confused state where the object is to make minorities become 'just like us' - namely, rational human beings driven primarily by

22 Industry Commission (1995). Charitable Organisations in Australia Report No.45, Industry Commission, Canberra.

23 Maddox, M (2005). God Under Howard; the Rise of the Religious Right in Australian Politics, Allen and Unwin, Sydney. 
economic factors, subscribing to values developed within a predominantly Christian tradition, a dominant language and a common loyalty to a defined 'nation', which over-rides other loyalties and former homelands. The clearest enunciation of such expectations can be gained from the speeches on Australian values delivered by John Howard from his Esperance address of 1988 to his election campaigning of $2007^{24}$. Essentially these are demands for cultural minorities to change their ways and for the majority to accept them graciously when they do. Politically this works well where the majority is either irreligious or subscribes to broadly defined versions of the dominant (usually Christian) creed. It ceased to work for Howard and his mentor George Bush when their official versions of national values became too narrow to cater for increasingly diverse electorates ${ }^{25}$.

If integration is to have any agreed meaning it must distinguish between assimilation - where individuals become indistinguishable from a national norm - and multiculturalism - where different cultures (including languages and religions) persist and are encouraged by authority to do so 'within strictly defined limits' as the Galbally definition of 1978 puts it. Obviously these two extremes are ideal types rather than legislated policies. Canada recognises that 'visible minorities' will not be fully assimilated because they look different from the majority, who consequently may treat them differently. No other society has adopted this common sensical but controversial approach, nor is it likely that Australia will. It lumps together Somali refugees, Indian academics and Aborigines, with very little in common except for potential vulnerability to prejudice. Today it would need to include Muslims and others wearing religiously distinctive clothing. Being 'visual' is defined by the perceptions of the majority population. In Australia the defining common denominator was language, through the category Non-English Speaking Background (NESB), now replaced by Culturally and Linguistically Diverse (CALD). These also lump together a wide variety of 'different' people.

Multiculturalism has had to be defended against claims that it is divisive, encourages loyalties to societies other than Australia, preserves conservative and reactionary values and practices and, of course, delays assimilation ${ }^{26}$. The 'strictly defined limits' have never been defined in practice and many involve religious beliefs and practices. The expectation that immigrants will accept equality of the sexes as a basic value began to appear in the late 1980s as Muslim immigration increased following the wars in Lebanon, Somalia and Afghanistan. Yet the two largest religious denominations - the Catholic Church and the Sydney Anglican diocese - do not accept gender equality within

24 Markus, A (2001). Race: John Howard and the Remaking of Australia, Allen and Unwin, Sydney.

25 Lohrey, A (2006). Voting for Jesus, Quarterly Essay, Melbourne.

26 Parekh, Lord B (2006). Rethinking Multiculturalism, Palgrave Macmillan, Basingstoke (UK). 
their organisations, as they have no women clergy. Neither do the Orthodox Churches. Some prestigious gentlemen's clubs in the major cities still do not accept women members. Religious and social organisations are, consequently, exempted from the prohibition on gender discrimination. Whether religious spokespersons can lawfully abuse other religions (as they have been doing for centuries) became controversial with the case of the Islamic Council of Victoria's legal action against two Pentecostalist ministers in Melbourne ${ }^{27}$.

Apart from the important religious dimension, there is an uncertain emphasis on individual or collective responsibility in recent formulations. Assimilation in its classic Australian form, between 1947 and the 1960s, assumed a common physical appearance within the terms of the White Australia policy; this is now redundant. It assumed the adoption of English to the exclusion of other languages; this has finally sunk in that many people can converse adequately in more than one language. It assumed that immigrants who arrived after 20-30 years of socialisation elsewhere would drop everything they knew and adopt a uniquely Australian culture; the popularity of ethnic festivals and food has laid that to rest. This extreme assimilationism had become dysfunctional by the 1960s. There is no likelihood of any government urging its return, though there were echoes of it in the tests introduced for intending citizens by the Howard government and subsequently revised by Labor. The assumption that all concessions would be made by minority groups and individuals was talked out in a series of official enquiries in the 1970s and 1980s.

At this stage of policy discourse it is hard to see what distinguishes the newly fashionable approach of integration from its predecessor multiculturalism. Clearly it is directed at changing the attitudes of many Muslims and thus gaining their acceptance by the majority population. The Commonwealth-State National Action Plan to Build on Social Cohesion, Harmony and Security, developed in 2005-2006, 'seeks to foster connections and understanding between Muslim and non-Muslim Australians and reinforce major contributions that all Australian can make to our country's future'. This joint effort by the Commonwealth and State governments focuses on 'education, employment, integration and security' through a modest programme of projects ${ }^{28}$.

While cultural diversity is mentioned in the DIAC introductory kit, multiculturalism is not. But nothing in official policy envisages the disappearance of Islam as a significant Australian religion. Nor does it require Christians to change their ancient attitudes towards Islam, provided they do not express these in unacceptably harsh terms. If religious activities are to continue unaffected, religious schools to be subsidised, religions to be tax exempt, free to advocate

27 Deen, H (2008). The Jihad Seminar, University of Western Australia Press, Perth.

28 Department of Immigration and Citizenship (2008). Community Projects 2007-2008, http://www.immi. gov.au/media/publications/multicultural/pdf_doc/Community. 
a range of highly controversial views, conduct their affairs in languages other than English and answer to leaders outside Australia, then integration will look rather like multiculturalism. No government is likely to change this situation even if the descriptive words are changed. As Shakespeare so wisely put it 'what's in a name? That which we call a rose by any other name would smell as sweet'. Religious variety will have saved secular multiculturalism. It has already posed a challenge to assimilation.

Table 1 Twenty largest religions in Australia by declared adherents and by the percentage of Australian citizenship for the total

\begin{tabular}{|c|c|c|}
\hline Religion & $\begin{array}{l}\text { Declared } \\
\text { adherents }\end{array}$ & $\begin{array}{l}\text { Percentage of Australian citizenship for the } \\
\text { total }\end{array}$ \\
\hline (Western) Catholics & 5087114 & $92.3 \%$ \\
\hline Anglican & 3716379 & $92.2 \%$ \\
\hline Uniting Church & 1135426 & $94.8 \%$ \\
\hline Presbyterian & 583397 & $87.7 \%$ \\
\hline Buddhist & 418757 & $76.3 \%$ \\
\hline Greek Orthodox & 374576 & $96.1 \%$ \\
\hline Islam & 340392 & $77.2 \%$ \\
\hline Baptist & 316741 & $89.9 \%$ \\
\hline Lutheran & 251105 & $90.4 \%$ \\
\hline Hinduism & 148125 & $57.9 \%$ \\
\hline Assemblies of God & 94893 & $87.5 \%$ \\
\hline Judaism & 88829 & $90.7 \%$ \\
\hline $\begin{array}{l}\text { Undefined } \\
\text { Pentecostal }\end{array}$ & 88534 & $86.5 \%$ \\
\hline Jehovah's Witnesses & 80916 & $88.4 \%$ \\
\hline Salvation Army & 64200 & $94.4 \%$ \\
\hline $\begin{array}{l}\text { Seventh Day } \\
\text { Adventists }\end{array}$ & 55254 & $86.7 \%$ \\
\hline $\begin{array}{l}\text { Latter Day Saints } \\
\text { (Mormons) }\end{array}$ & 52147 & $76.4 \%$ \\
\hline $\begin{array}{l}\text { Macedonian } \\
\text { Orthodox }\end{array}$ & 48082 & $96.1 \%$ \\
\hline Churches of Christ & 47772 & $94.6 \%$ \\
\hline Serbian Orthodox & 39967 & $93.6 \%$ \\
\hline $\begin{array}{l}\text { (No Religion - as } \\
\text { stated) }\end{array}$ & 3706554 & $89.6 \%$ \\
\hline
\end{tabular}


Multiculturalism and Integration

Table 2 Religions grouped by 'regions of origin' and largest groups from that region

\begin{tabular}{llr}
\hline Region of origin & Largest groups from that region & Declared adherents \\
\hline Great Britain & Anglican, Uniting & 5886833 \\
Ireland and Europe & Catholic, Orthodox & 600244 \\
North America & Pentecostal, Adventist & 451912 \\
Middle East & Islam, Orthodox & 438639 \\
Asian & Buddhist, Hinduism & 602593 \\
Indigenous and Pacific & Traditional, Aboriginal & 12498 \\
Non-Specific/Australian & Undefined Christians & 450392 \\
\hline $\begin{array}{l}\text { The 'region of origin' indicates the region from which most adherents arrived or in which the } \\
\text { denomination has its greatest strength (hence the separation of Ireland from Great Britain). } \\
\text { Choices are generalised and may be arbitrary. }\end{array}$ \\
\hline
\end{tabular}

Source: adapted from the 2006 Commonwealth Census.

Table 3 Numbers with graduate or postgraduate qualifications for major religions and percentage for total figures for adults in that religion

\begin{tabular}{lcc}
\hline Religion & Graduates & $\begin{array}{c}\text { Percentage of adult } \\
\text { number }\end{array}$ \\
\hline (No Religion) & 601745 & $16.2 \%$ \\
(Western) Catholic & 422170 & $8.3 \%$ \\
Anglican & 390563 & $10.5 \%$ \\
Uniting Church & 141747 & $12.5 \%$ \\
Buddhist & 80241 & $19.2 \%$ \\
Presbyterian & 67345 & $11.5 \%$ \\
Hindu & 60731 & $41.0 \%$ \\
Baptist & 50101 & $15.8 \%$ \\
Islam & 44158 & $13.0 \%$ \\
Greek Orthodox & 41024 & $10.9 \%$ \\
Lutheran & 33571 & $13.4 \%$ \\
Judaism & 28243 & $32.9 \%$ \\
Assemblies of God & 13096 & $13.8 \%$ \\
Pentecostals* & 12526 & $14.2 \%$ \\
\hline
\end{tabular}

*not further defined

Source: 2006 Commonwealth Census of Population and Housing 